\title{
IMPACT OF NITRIC OXIDE SYNTHESIS MODULATORS ON THE CYTOKINES PROFILE IN EXPERIMENTAL ANTIPHOSPHOLIPID SYNDROME
}

\author{
*O.Z. Yaremchuk, K.A. Posokhova, I.P. Kuzmak, M.I. Kulitska, \\ O.O. Shevchuk, A.S. Volska, P.H. Lykhatskyi \\ I. HORBACHEVSKY TERNOPIL NATIONAL MEDICAL UNIVERSITY, TERNOPIL, UKRAINE
}

Background. Antiphospholipid syndrome (APS) is an autoimmune disease characterized by the presence of specific antibodies.

Objective. The aim of the study was to investigate the effect of combined use of L-arginine and aminoguanidine on cytokine profile (IL-1 $\beta, I L-6, T N F-a, I L-4, I L-10)$ in experimental APS.

Methods. The study was performed on BALB/C female mice. L-arginine (25 mg/kg) and aminoguanidine $(10 \mathrm{mg} / \mathrm{kg})$ were used for correction. Serum cytokines concentrations were assessed using an ELISA test.

Results. It was found that in APS the concentration of proinflammatory cytokines IL-1 $\beta$, IL-6 and TNF-a increases in 3.2, 2.3 and 4.5 times respectively, compare to the control. At the same time a decrease of the IL-4 and IL-10 in 1.9 and 2.2 times was evidenced.

Aminoguanidine, a selective iNOS inhibitor, caused a significant decrease of TNF-a by $57 \%(p<0.001)$, but there were no changes in IL-1 $\beta, I L-6, I L-4$ and IL-10 compare to the APS-group. L-arginine combined with aminoguanidine caused a significant decrease in the concentration of IL-1 $\beta$ by $30 \%(p<0.01)$, IL- $6-$ by $16 \%$ $(p<0.05)$, TNF- $a-$ by 59\% ( $p<0.001)$ compare to the control. At the same time, the concentration of IL-4 increased by $35 \%(p<0.01), I L-10-$ by $25 \%(p<0.005)$.

Conclusions. Combined use of the precursor of the NO synthesis L-arginine and aminoguanidine, a selective iNOS inhibitor, leads to a decrease in the concentrations of IL-1 $\beta, I L-6, T N F-a$ and an increase of IL-4 and IL-10 compare to the group of the BALB/c mice with APS and the group of animals administered with aminoguanidine.

KEY WORDS: antiphospholipid syndrome; cytokines; nitric oxide; L-arginine; aminoguanidine.

\section{Introduction}

Antiphospholipid antibody syndrome (APS) is an autoimmune condition characterized by the presence of antiphospholipid antibodies (aPL) [1], encompassing primary APS, secondary APS, seronegative APS (SNAPS) and catastrophic APS (CAPS) [2]. Secondary APS can be found in association with other autoimmune conditions such as systemic lupus erythematosus, rheumatoid arthritis, autoimmune thyroid disease, Crohn's disease, Sjogren syndrome, systemic sclerosis, lymphoma or leukemia, malignancies of the ovary and cervix, drug induced as with oral contraceptive pills or in infectious disease such as HIV or syphilis [1]. In CAPS a systemic inflammatory response, systemic endothelial dysfunction and DIC develop. These processes are the pathogenetic basis for development of multiple organ failure $[3,4]$. SNAPS is negative *Corresponding Author: Yaremchuk Olha, Ph.D., Associate Professor of the Department of Medical Biochemistry, I. Horbachevsky Ternopil National Medical University, Maidan Voli, 1, Ternopil, Ukraine.E-mail: yaremchuk@tdmu.edu.ua for lupus anticoagulant and antiphospholipid antibodies [2].

The diagnostic APS criteria are anticardiolipin $(\mathrm{aCL})$, antiß2-glycoprotein-I (aß2GPI) and lupus anticoagulant (LA) $[1,5]$. APS can be classified only in the presence of thrombotic (non-inflammatory arterial, venous or small vessel thrombosis) obstetric complications (death of one or more morphologically normal fetus at or beyond the $10^{\text {th }}$ week of gestation; one or more premature birth of normal fetus before the $34^{\text {th }}$ week due to eclampsia, pre-eclampsia or placental insufficiency), or increased aPL level [2]. The mechanisms of thrombosis in APS have not been fully studied yet [6].

aß2GPI antibodies are central in pathogenic APS mechanisms and, although the full pathogenesis of APS is not clear yet, the binding of these aPL antibodies to the antigens on the cell surface of platelets, monocytes, endothelial cells and trophoblasts triggers intracellular signaling with subsequent activation and alteration 
of diverse cell functions. Cellular activation starts after the binding of the complex aß2GPI antibody/ $\beta 2$ GPI $[5,7]$. $\beta 2$ GPI is the most important antigenic target [2]. Platelets activation and the subsequent release of thromboxane favor their aggregation. Thrombosis at the fine vasculature of the target organ is thought to be more dependent from antibodies against the anticoagulant AnV. Endothelial cells and monocytes activation determine a proaggregation status due to up-regulated expression of adhesion molecules, such as E-selectin, and release of tissue factor (TF) and proinflammatory cytokines [5]. Many patients with aPL antibodies remain asymptomatic [2].

An important factor in APS immunopathogenesis is dysregulation of cytokine balance with increased synthesis of proinflammatory cytokines $[8,9]$.

Cytokines are the most versatile system of regulation. Cytokines, being synthesized at the inflammation site, affect virtually all cells involved in the inflammation development, as well as granulocytes, macrophages, fibroblasts, endothelial cells, epithelium cells, T and B lymphocytes [10].The inflammatory processes are controlled by the proinflammatory (IL-1, IL-2, IL-6, IL-8, IL-12, TNF-a, IFN) and antiinflammatory (IL-4, IL-10, TGF) cytokines [11]. Therefore, the study of pathobiochemical mechanisms of APS development, particularly establishment of the role of the cytokine system in development of this pathology, and search for effective methods of its treatment is an urgent and social issue $[1,6,11,12]$.

One of the links that are involved in the mechanisms of APS development is the nitric oxide (NO) system. In obstetric APS, the synthesis and bioavailability of nitric oxide (NO), which is involved in the regulation of vascular tone and blood coagulation properties, are impaired in the endothelium [4]. According to Cella M [13], a decrease in NO levels causes abortion and premature birth. On the other hand, NO overproduction mediated with inducible NO synthase (iNOS) increases uterine contractions and the risk of miscarriage [13]. Contradictions of the existing information on the involvement of the NO system in APS development as well as on the efficacy of NO precursors in reducing the manifestations of this pathology necessitates further study of the role of this system in APS.

The objective of research is to investigate the effect of combined use of L-arginine and aminoguanidine on cytokine profile (concent- ration of IL-1 $\beta$, IL-6, TNF- $\alpha$, IL-4, IL-10) in experimental antiphospholipid syndrome.

\section{Methods}

Female BALB/c mice, which were kept on a standard vivarium diet, were used in the research. The experiments were carried out following the principles of bioethics according to the "General Ethical Principles of Animal Experiments", approved by the First National Congress on Bioethics (Kyiv, 2001) and in accordance with the provisions of the "European Convention for the Protection of Vertebrate Animals used for Experimental and Other Scientific Purposes" (Strasbourg, 1986) and EU Directive 2010/10/63 EU for animal experiments.

APS was modeled using cardiolipin (Sigma, USA), which was injected intramuscularly four times (30 $\mu \mathrm{g}$ per 1 injection, the injection interval was 14 days) [14]. To enhance the effectiveness of the immune response, cardiolipin was emulsified in $75 \mu \mathrm{l}$ of complete Freund's adjuvant (first injection); subsequent injections were performed with incomplete Freund's adjuvant. APS was developing for 2 weeks after the last cardiolipin injection.

The experimental animals were divided into 4 groups: the $1^{\text {st }}$ - the intact; the $2^{\text {nd }}$ - the BALB/C mice with APS; the $3^{\text {rd }}$ - the animals with APS administered with aminoguanidine, the $4^{\text {th }}$ - the animals with APS administered with L-arginine in combination with aminoguanidine. L-arginine (Sigma, USA, $25 \mathrm{mg} / \mathrm{kg}$ ) and aminoguanidine (Khimlaboratorreaktiv, Ukraine, $10 \mathrm{mg} / \mathrm{kg}$ ) were administered intraperitoneally once a day for 10 days after APS development. The animals of the control group were managed with the same volumes of the solvent intraperitoneally. In 10 days after confirmation of APS the animals were taken out of the experiment by thiopental sodium anesthesia (intraperitoneal administration of $1 \%$ solution at a dose of $50 \mathrm{mg} / \mathrm{kg}$ of animal body weight).

The concentration of cytokines IL- $1 \beta$, IL- 6 , TNF-a, IL-10, IL-4 in the serum of BALB/c mice was determined by enzyme immunoassay using standard kits adapted for mice of Express Biotech International, USA (Mouse IL-1 $\beta$ ELISA Assay, Mouse IL-6 ELISA Assay, Mouse TNF-a ELISA Assay, Mouse IL-10 ELISA Assay, Mouse IL-4 ELISA Assay). The concentration of cytokines was expressed in $\mathrm{pg} / \mathrm{ml}$.

Statistical processing of digital data was performed by means of Excel software (Microsoft, USA) and STATISTICA 6.0 (Statsoft, USA) using non-parametric methods of estimation 
for the attained data. The arithmetic mean (M), its variance and standard error of the mean $(\mathrm{m})$ were assessed for all parameters. The significant difference between the independent quantitative values was determined using the MannWhitney test. The changes were statistically significant at $p \leq 0.05$.

\section{Results}

According to the attained results, an increase of the concentration of IL-1 $\beta$ in 3.2 times $(p<0.001)$ was proved in the BALB/c mice with APS compare to the control (Fig. 1).

An increase in the concentration of IL- 6 in 2.3 times $(p<0.001)$ in the serum of the animals with APS was evidenced compare to the intact animals (Fig. 2).

TNF- $a$ concentration increased in 4.5 times $(p<0.001)$ in the serum of the BALB/c mice with APS compare to the control (Fig. 3).

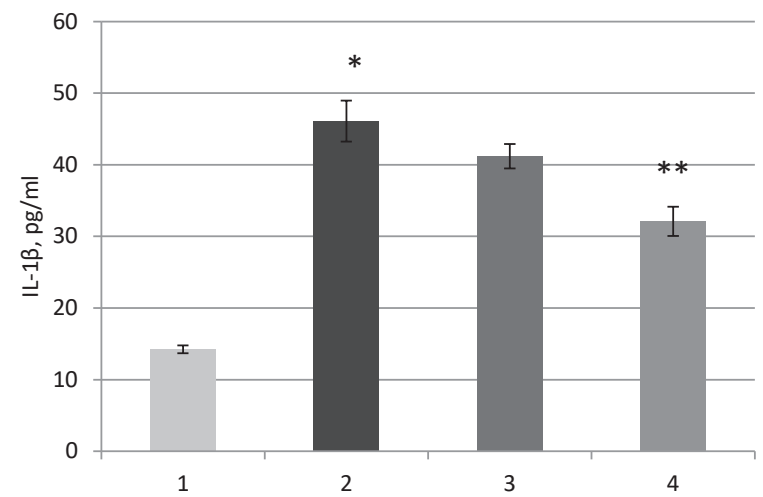

Fig. 1. IL-1 $\beta$ content in the blood serum of the BALB/C mice with APS in the case of administration of L-arginine and aminoguanidine $(M \pm m, n=10)$.

Notes: Herein, and Figures 2-5.

Conventional name of animal groups: 1 - Control; 2-Antiphospholipid syndrome (APS); 3 - APS + aminoguanidine; 4 $A P S+L$-arginine+aminoguanidine.

$*$ - $p<0.05$ compare to the control group;

** $-p<0.05$ compare to the group of animals with APS.

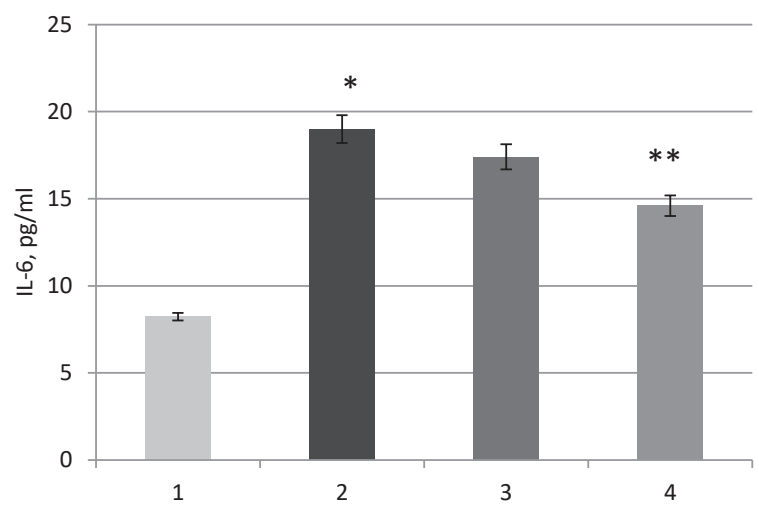

Fig. 2. IL-6 content in the blood serum of the BALB/C mice with APS in the case of administration of L-arginine and aminoguanidine $(M \pm m, n=10)$.
At the same time, the anti-inflammatory cytokine IL-4 concentration reduced in 1.9 times $(p<0.001)$ and IL-10 - in 2.2 times $(p<0.001)$ compare to the control (Fig. 4-5).

The administration of aminoguanidine, a selective iNOS inhibitor, did not cause significant changes concentrations of IL-1 $\beta$ and IL- 6 in the serum of the BALB/c mice with APS compare to the control (Fig. 1-2). In the case of aminogua-

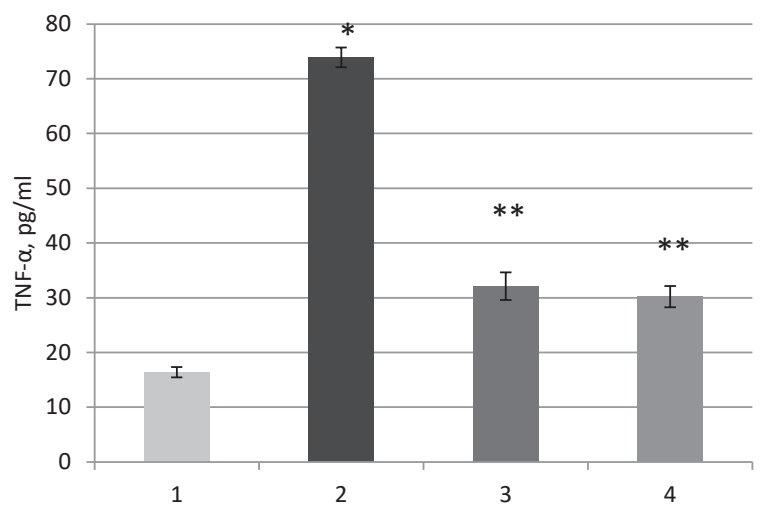

Fig. 3. TNF-a content in the blood serum of the BALB/c mice with APS in the case of administration of L-arginine and aminoguanidine $(M \pm m, n=10)$.

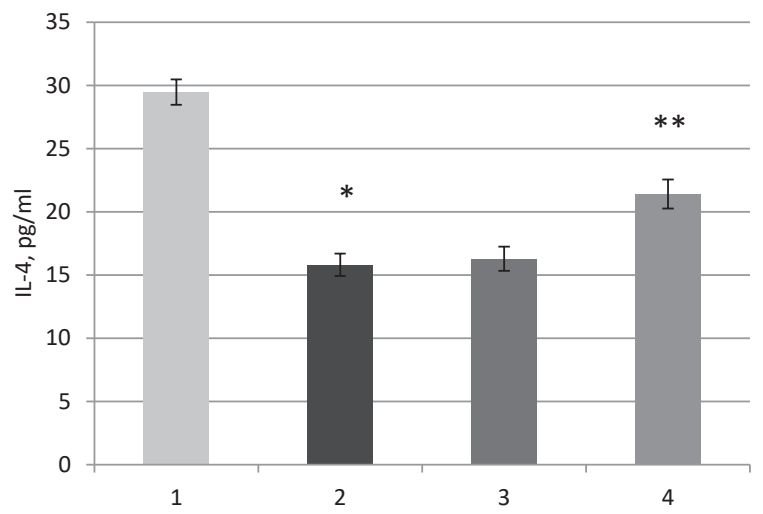

Fig. 4. IL-4 content in the blood serum of the BALB/c mice with APS in the case of administration of L-arginine and aminoguanidine $(M \pm m, n=10)$.

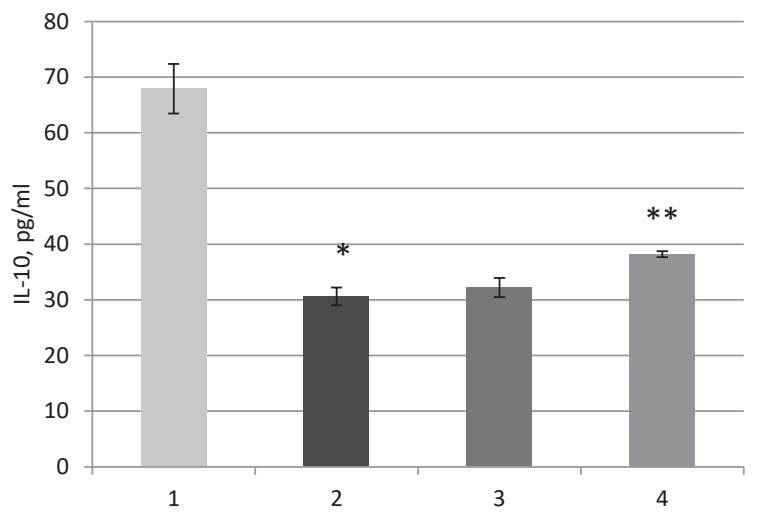

Fig. 5. IL-10 content in the blood serum of the BALB/C mice with APS in combined administration of L-arginine and aminoguanidine ( $M \pm m, n=10)$. 
nidine use, a significant decrease in the concentration of TNF-a by $57 \%(p<0.001)$ was evidenced compare to the intact animals (Fig. 3). It was found out that, under the influence of aminoguanidine, the concentrations of IL-4 and IL-10 did not change significantly compare to the control group of animals (Fig. 4-5).

In the case of administration of the predecessor of the synthesis of NO L-arginine in combination with aminoguanidine, a significant decrease in the concentration of IL-1 $\beta$ by $30 \%$ $(p<0.01)$, IL- 6 by $16 \%(p<0.05)$, TNF-a by $59 \%$ $(p<0.001)$ was established compare to the control (Fig. 1-3). At the same time, the concentration of anti-inflammatory cytokines IL-4 increased by $35 \%(p<0.01)$ and IL-10 - by $25 \%$ $(p<0.005)$ compare to the control animals (Fig. 4-5).

The results of the study proved that a significant decrease in the concentration of IL- $1 \beta$ by $22 \%(p<0.05)$, IL- 6 by $23 \%(p<0.005)$ was evidenced in the case of combined administration of L-arginine and aminoguanidine compare to the indicators of the $3^{\text {rd }}$ group of animals, which were administered with aminoguanidine (Fig. 1-2). An increase of the antiinflammatory cytokine IL-4 concentration by $32 \%(p<0.05)$ and IL-10 by $19 \%(p<0.05)$ was proved compare to the $3^{\text {rd }}$ group of the BALB/c mice administered with aminoguanidine (Fig. 4-5).

\section{Discussion}

Besides the pathogenic role of the $\mathrm{aPL}$, proinflammatory cytokines and chemokines are significant in the pathogenesis of APS [12]. IL-1, TNF-a and endotoxins induce tissue factor (TF) expression in endothelial cells, monocytes, macrophages promoting blood clotting $[10,15]$. The inhibitors of IL-1 production are IL-4, IL-10, IL-12, TNF-a [16]. IL-6 is involved in regulation of $T$ and $B$ cell interactions, macrophage, endotheliocytes activity. IL- 6 induces production of acute-phase proteins, stimulates hematopoiesis and platelet formation [16].

The attained results on increased concentrations of proinflammatory cytokines (IL-1 $\beta$, IL-6, TNF- $a$ ) in the serum of the experimental animals with APS conform with the literature $[6,17,18]$. According to N.V. Seredavkina [6], an increased concentration of IL- 6 and TNF- $\alpha$ in the patients with APS compare to the control group was established. It is not clear whether aPL affect endothelial cells directly or through TNF-a. Regardless of the mechanism, the prothrombotic condition, typical of APS, is asso- ciated with both significantly increased aPL levels as well as high TNF-a concentration [11]. According to J. Swadzba et al. [15] TNF-a is one of the main proinflammatory cytokines in APS; its level is increased and reflects pathological processes in endothelial cells. According to the literature, aPL and TNF-a can activate the endothelium and induce prothrombotic phenotype of endothelial cells, leading to increased thrombin production. Activation of endothelial cells causes upregulation of TF, which has been suggested to be a major potential mechanism of APS-related thrombosis. Once endothelial cells are activated, TF regulation can be more enhanced by a synergizing effect of TNF-a and factor $\mathrm{Xa}$, thus expression of adhesion molecules (ICAM-1, VCAM-1, E and P selectins) and formation of endothelial microparticles take place [15].

According to A. Farzaneh-Far et al. [17], who investigated the levels of CRP IL 6, ISAM-1, pTNF a-P2, pTNF a-P2 in the patients with SLE, only increased pTNF a-P1 and pTNF a-P2 were associated with aPL positivity. According to NV Seredavkin a negative correlation between CRP and IgG $\beta 2 \mathrm{GP} 1$ levels was established [6]. R.R. Forastiero et al. [18] established that IL 6 levels were greater in the patients with APS and aPA carriers than in the control group. TNF concentration was the same in the patients with APS and aPA carriers but higher than in the control group. In the patients with positive aPA, a direct correlation between IL 6 and TNF a was proved [18]. Under the experimental conditions it has been established that TNF-a may manifest antiplatelet and antithrombotic activity [15]

According to the literature, IL-1 $\beta$ activates the synthesis of IL-6, S100B, a1-antihymotrypsin, inducible nitric oxide synthase (iNOS) causing increased NO synthesis $[19,20]$. The iNOS is crucial in the primary proinflammatory response in macrophages [21]. AG is a nucleophilic hydrazine compound, structurally similar to L-arginine in that these compounds contain two chemically equivalent guanidino nitrogen groups and to L-arginine analogues that competitively inhibit NO synthase. AG completely prevents inflammatory stimuli induced formation of NO, and it is a potent inhibitor of the cytokine-inducible isoform NOS [22].

The results of our studies proved that introduction of aminoguanidine, a selective iNOS inhibitor, did not cause significant changes in the concentration of proinflammatory cytokines (IL-1 $\beta$ and IL-6) and anti-inflammatory cytokines (IL-4 and IL-10) in the serum of the BALB/c mice 
with APS compare to the control group of animals. At the same time, in the case of aminoguanidine administration a significant decrease in TNF-a concentration was proved compare to the intact animals. According to EI Ferreira et al. [23] aminoguanidine decreases TNFa levels, oxidative stress indicators, and NO metabolites.

It is established that increased concentrations of TNF-a are associated with pregnancy miscarriage in APS $[6,8]$, endotheliocytes activation, and chemokine amplification that leads to subendothelial leukocyte accumulation, endothelial dysfunction, microcirculation disturbances [16].

Early endothelial dysfunction was observed in APS [24]. Patients with APS displaying thrombosis exhibited low plasma levels of nitrites and nitrates, which are the stable metabolites of NO breakdown. aPL can act as antagonists of endothelial nitric oxide synthase (eNOS) through $\beta 2 \mathrm{GPI}$, and this interaction may impair NO synthesis. In particular, attenuation of eNOS activation by aPL was mediated by reduced phosphorylation of eNOS serine. This inhibition of eNOS phosphorylation was shown to be dependent upon protein phosphatase 2A, $\beta 2$ GPI, and apolipoprotein E receptor 2. aPL inhibition of eNOS activity contributes to thrombus formation, increased leukocyte adhesion, and alterations in vascular tone [4].

It is established that violation of the bioavailability of NO may be one of the causes of endothelial dysfunction. This may be associated with both the lack of substrate for NO L-arginine synthesis as well as formation of superoxide anion which rapidly binds and inactivates NO [24].

NO synthesis is not dependent on L-arginine concentration in physiological states. In pathological conditions, the availability of L-arginine may determine production of NO. It is proved that L-arginine is necessary for adequate translation of iNOS. When iNOS is being activated, superoxide anion is produced, which forms a highly reactive peroxynitrite, which in turn produces nitrosylation of amino acid residues sensitive to it, especially tyrosine, that leads to conformational changes in the structure of protein molecules. With administration of L-arginine the functional characteristics of T-cells enhance, production of antibodies increases as well. NO-dependent effect of L-arginine on the immune system may be hormone-mediated [25].

The next objective of our study was to investigate the effect of combined use of L-argi- nine and aminoguanidine on cytokine profile in APS.

In the case of the use of the precursor of NO L-arginine synthesis in combination with aminoguanidine, a selective iNOS inhibitor, a significant decrease in the concentration of proinflammatory cytokines (IL-1 $\beta$, IL-6, TNF-a) and an increase in the concentration of antiinflammatory cytokines (IL-4, IL-10) was established compare to the control group of animals. The attained results are consistent with the literature $[25,26]$. These effects can be explained by the fact that glutamine formed from L-arginine is a conditionally essential amino acid and reduces the level of TNF-a soluble receptors [26]. According to VM Sheibak et al. [25] administration of L-arginine decreases the level of IL-6.

According to P. Soltesz et al. [12], besides the conventional Th1 pathway, Th2 cytokines are crucial in the mechanisms of APS development, i.e. IL-4 and IL-10. Various immunocompetent cells regulate the proinflammatory cascade that leads to cytokine imbalance and activated circulating lymphocytic pool in APS. This proinflammatory process leads to endothelial dysfunction, development of arterial and venous thrombosis [12]. As a result of the research, a decrease in anti-inflammatory cytokines (IL-4, IL-10) in APS was established; the results are consistent with the literature [11, 12]. According to P. Soltesz et al. [12], the markers of endothelial dysfunction positively correlate with IL-4 levels in APS. It allows suggesting that by activation of the humoral and cellular immune responses, IL-4 is crucial in development of endothelial dysfunction, atherosclerosis, arterial and venous thrombosis. IL-4 stimulates $B$ and $T$ cell proliferation as well as differentiation of CD4 + T cells into Th2 cells [12].

According to A. Menachem et al. [11] cytosolic and secreted IL-10 and IFN-y levels in eAPS mice were lower at 6 and 15 weeks and higher at 24 weeks after immunization compared to adjuvant mice. IL-10 is significant in autoimmune diseases. As a result of other studies, IL-10 level was decreased in the serum of the patients with APS [12].

IL-10 inhibits secretion of IL-4, IL-5 and IFN-y, growth factors and chemokines, and therefore acts as a key counter-regulator of autoimmune processes [12]. One of the functions of IL-10 is inhibition of the synthesis of proinflammatory cytokines: IL-1, IL-6, IL-12 and TNFa via a STAT3-dependent mechanism [27] and enhancement of IL-1 receptor antagonist 
expression [19]. Decreased level of IL-10 in the serum in cases of APS compare to the control confirms the fact that IL10-mediated processes are impaired in APS that is why it leads to vascular damage [12].

Low IL-10 levels enable TNF-a unregulated production, resulting in procoagulant state. Decreased IL-10 levels can be associated with lymphocyte activation, which leads to the continuation of the autoimmune response. During the B-cell activation, IL-10 delivers signals that promote the apoptosis of B cells [11].

\section{Conclusions}

Thus, that in the serum of BALB/c mice with APS, an increase in the concentrations of proinflammatory cytokines (IL-1 $\beta$, IL-6, TNF-a) and a decrease in the concentrations of anti-inflammatory cytokines (IL-4 and IL-10) was established compare to the control parameters. With the introduction of aminoguanidine, a selective iNOS inhibitor, a decrease in the concentration of TNF-a was proved compare to that of the animals with APS. In the case of the use of the precursor of NO synthesis L-arginine in combination with aminoguanidine, a significant decrease in concentrations of IL-1 $\beta$, IL- 6 , TNF- $\alpha$ and an increase of IL-4 and IL-10 was evidenced compare to the group of BALB/c mice with APS and the group of animals administered with aminoguanidine.

\section{Funding}

This research received no external funding. Conflict of Interests

The authors declare no conflict of interest. Authors Contributions

Yaremchuk O.Z. - writing - original draft, conceptualization, project administration, methodology, investigation, formal analysis, Posokhova K.A. - supervision, conceptualization, writing review \& editing, Kuzmak I.P. - data curation, Kulitska M.I. - investigation, Shevchuk O.O. investigation, writing - review \& editing, Volska A.S. - investigation, Lykhatskyi P.H. - data curation.

\title{
ВПЛИВ МОДУЛЯТОРІВ СИНТЕЗУ ОКСИДУ АЗОТУ НА ПОКАЗНИКИ ЦИТОКІНОВОГО ПРОФІЛЮ ПРИ ЕКСПЕРИМЕНТАЛЬНОМУ АНТИФОСФОЛІПІДНОМУ СИНДРОМІ
}

\author{
О.3. Яремчук, К.А. Посохова, І.П. Кузьмак, М.І. Куліцька, \\ О. О. Шевчук, А.С. Вольська, П.Г. Лихацький \\ ТЕРНОПІЛЬСЬКИЙ НАЦІОНАЛЬНИЙ МЕДИЧНИЙ УНІВЕРСИТЕТ IМЕНІ І. Я. ГОРБАЧЕВСЬКОГО, \\ ТЕРНОПIЛЬ, УКРАЇНА
}

Вступ. Антифосфоліпідний синдром (АФС) - це автоімунне захворювання, яке характеризується наявність антифосфоліпідних антитіл, артеріальними та венозними тромбозами, тромбоцитопенією, невиношування вагітності.

Мета дослідження. Дослідити вплив комбінованого застосування L-аргініну та аміногуанідину

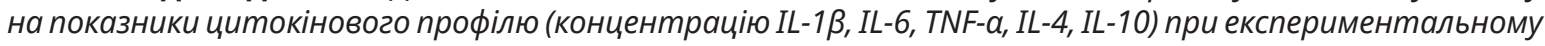
антифосфоліпідному синдромі.

Методи дослідження. Дослідження виконано на мишах-самках лінії BALB/c, в яких моделювали АФC. Для корекції використовували L-аргінін (25 мг/кг) та аміногуанідин (10 мг/кг). Визначення концентрації цитокінів IL-1及, IL-6, TNF-a, IL-10, IL-4 у сироватці крові мишей BALB/c проводили методом імуноферментного аналізу з використанням стандартних наборів реактивів.

Результати й обговорення. Отримані результати свідчать, що у сироватці крові мишей BALB/c

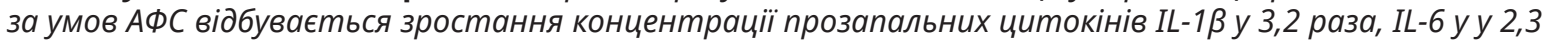
раза, TNF-а в 4,5 разів, відносно контролю. Спостерігалось зниження концентрації протизапальних цитокінів IL-4 в 1.9 раза та IL-10 в 2,2 раза у групі тварин з АФС, порівняно із показниками контролю.

На фоні застосування селективного інгібітора іNOS аміногуанідину встановлено достовірне зниження концентрації TNF-а на 57 \% (р<0.001), проте концентрація IL-1及, IL-6 IL-4 ma IL-10 достовірно не змінювалася у сироватці крові мишей $B A L B / c$ з АФС, порівняно з показниками тварин з АФС. На фоні застосування попередника синтезу NO L-аргініну в комбінації з аміногуанідином встановлено достовірне

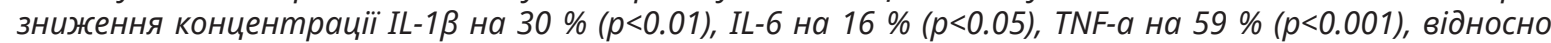
контролю. Водночас зростала концентрація протизапальних цитокінів IL-4 на 35 \% (p<0.01) ma IL-10 на 25\% (p<0.005), порівняно з показниками групи мишей BALB/c з AФC. 
Висновки. Встановлено, що комбіноване застосування попередника синтезу NO L-аргініну та селективного інгібітора іNOS аміногуанідину призводить до зниження концентрації IL-1 $\beta$, IL-6, TNF-a та зростання IL-4 ma IL-10, порівняно з показниками групи мишей BALB/c з AФС та групи тварин, яким вводили аміногуанідин.

КЛЮЧОВІ СЛОВА: антифосфоліпідний синдром; цитокіни; оксид азоту; L-аргінін; аміногуанідин

\section{Відомості про авторів}

Яремчук Ольга Зеновіївна - кандидат біологічних наук, доцент кафедри медичної біохімії Тернопільського національного медичного університету імені І.Я. Горбачевського, Тернопіль, Україна.

Посохова Катерина Андріївна - доктор медичних наук, професор кафедри фармакології з клінічною фармакологією Тернопільського національного медичного університету імені I.Я. Горбачевського.

Кузьмак Ірина Петрівна - кандидат біологічних наук, доцент кафедри медичної біохімії Тернопільського національного медичного університету імені І.Я. Горбачевського.

Куліцька Марія Іванівна - кандидат біологічних наук, доцент кафедри медичної біохімії Тернопільського національного медичного університету імені І.Я. Горбачевського.

Шевчук Оксана Олегівна - кандидат медичних наук, доцент кафедри фармакології з клінічною фармакологією Тернопільського національного медичного університету імені І.Я. Горбачевського.

Вольська Аліна Станіславівна - кандидат біологічних наук, доцент кафедри фармакології з клінічною фармакологією Тернопільського національного медичного університету імені I.Я. Горбачевського.

Лихацький Петро Григорович - доктор біологічних наук, професор кафедри медичної біохімії Тернопільського національного медичного університету імені І.Я. Горбачевського.

\section{Information about the authors}

Yaremchuk O.Z. - Ph.D., Associate Professor of Medical Biochemistry Department, I. Horbachevsky Ternopil National Medical University, Ternopil, Ukraine.

ORCID 0000-0001-5951-1137, e-mail: yaremchuk@tdmu.edu.ua

Posokhova K.A. - MD, Ph.D., DSc., Professor of Pharmacology and Clinical Pharmacology Department, I. Horbachevsky Ternopil National Medical University, Ternopil, Ukraine.

ORCID 0000-0002-2696-5738, e-mail: posokhova@tdmu.edu.ua

Kuzmak I.P. - Ph.D., Associate Professor of Medical Biochemistry Department, I. Horbachevsky Ternopil National Medical University, Ternopil, Ukraine.

ORCID 0000-0002-5035-8815, e-mail: kuzmak@tdmu.edu.ua

Kulitska M.I. - Ph.D., Associate Professor of Medical Biochemistry Department, I. Horbachevsky Ternopil National Medical University, Ternopil, Ukraine.

ORCID 0000-0001-7116-6655, e-mail: kulitskam@tdmu.edu.ua

Shevchuk 0.0. - MD, Ph.D., Associate Professor of Pharmacology and Clinical Pharmacology Department, I. Horbachevsky Ternopil National Medical University, Ternopil, Ukraine.

ORCID 0000-0003-2473-6381, e-mail: shevchukoo@tdmu.edu.ua

Volska A.S. - Ph.D., Associate Professor of Pharmacology and Clinical Pharmacology Department, I. Horbachevsky Ternopil National Medical University, Ternopil, Ukraine.

ORCID 0000-0002-4985-9559, e-mail:volska@tdmu.edu.ua

Lykhatskyi P.H. - Ph.D., DSc., Professor of Medical Biochemistry Department, I. Horbachevsky Ternopil National Medical University, Ternopil, Ukraine.

ORCID 0000-0002-0021-782X, e-mail: luhatsky@tdmu.edu.ua

\section{References}

1. Khangura RK, Cooper S, Luo GY. Antiphospholipid Antibody Syndrome: Pathogenesis, Diagnosis, and Management in Pregnancy. MaternalFetal Medicine. 2019 Jul 1;1(1):38-42.

doi: 10.1097/FM9.0000000000000007

2. Ahluwalia J, Sreedharanunni S. The Laboratory Diagnosis of the Antiphospholipid Syndrome. Indian
Journal of Hematology and Blood Transfusion. 2017 Mar 1;33(1):8-14. doi: $10.1007 / \mathrm{s} 12288-016-0739-y$

3. Bitsadze VO, Khizroeva DKh, Idrisova LE, etc. Catastrophic antiphospholipid syndrome. Pathogenesis. Obstetrics, Gynecology and Reproduction. 2015;2:32-53. (In Russian) doi: 10.17749/2070-4968.2015.9.2.032-053. 
4. Velásquez M, Rojas M, Abrahams VM, Escudero C, Cadavid ÁP. Mechanisms of Endothelial Dysfunction in Antiphospholipid Syndrome: Association with Clinical Manifestations. Frontiers in Physiology. 2018;9:1840.

doi: 10.3389/fphys.2018.01840

5. D'Angelo C, Franch O, Fernández Paredes L, Oreja-Guevara C, Núñez-Beltrán M, Comins A, Reale M, Sánchez-Ramón S. Antiphospholipid Antibodies overlapping in Isolated Neurological Syndrome and Multiple Sclerosis: Neurobiological Insights and Diagnostic Challenges. Frontiers in Cellular Neuroscience. 2019;13:107.

doi: 10.3389/fncel.2019.00107

6. Seredavkina NV, Reshetnyak TM, Aleksandrova EN and others. Marker of inflammation in patients with antiphospholipid syndrome with cardiovascular pathology. Scientific and Practical Rheumatology. 2010;5:37-43. (In Russian)

doi: 10.14412/1995-4484-2010-729

7. McDonnell T, Wincup C, Buchholz I, Pericleous C, Giles I, Ripoll V, Cohen H, Delcea M, Rahman $A$. The role of beta-2-glycoprotein I in health and disease associating structure with function: more than just APS. Blood reviews. 2019 Aug 16:100610.

doi:10.1016/j.blre.2019.100610

8. Berman J, Girardi G, Salmon J.E. TNF-alpha is a critical effector and a target for therapy in antiphospholipid antibody-induced pregnancy loss. J. Immunol. 2005; 174: 485-90.

doi: 10.4049/jimmunol.174.1.485

9. Shoenfeld Y, Meroni PL, Cervera R. Antiphospholipid syndrome dilemmas still to be solved: 2008 status. Annals of the rheumatic diseases. $2008 \mathrm{Apr}$ 1;67(4):438-42.

doi: 10.1136/ard.2007.083873

10. Madej PD, Piecha D, Pluta B, ZubelewiczSzkodzinska, Havrylyuk A, Kondratyuk M, et al. Immunological factors in etiopathogenesis of recurrent miscarriages. Lviv Medical Journal. 2015;3:89-95. (In Ukrainian)

11. Menachem A, ChapmanJ, Katzav A. Significant changes in the levels of secreted cytokines in brains of experimental antiphospholipid syndrome mice. Autoimmune diseases. 2012;2012:404815.

doi: $10.1155 / 2012 / 404815$

12. Soltesz P, Der H, Veres K, Laczik R, Sipka S, Szegedi G, et al. Immunological features of primary anti-phospholipid syndrome in connection with endothelial dysfunction. Rheumatology. 2008;47: 1628-34.

doi:10.1093/rheumatology/ken349

13. Cella M, Farina MG, Dominguez Rubio AP, Di Girolamo G, Ribeiro ML, Franchi AM. Dual effect of nitric oxide on uterine prostaglandin synthesis in a murine model of preterm labour. British Journal of Pharmacology. 2010 Oct;161(4):844-55.

doi: 10.1111/j.1476-5381.2010.00911.x

14. Zaichenko GV, Laryanovskaya YB, Deeva TV. etc. Morphological status of uterus and placenta in experimental modeling of gestational antiphospho- lipid syndrome in mice. Ukrainian Medical Almanac. 2011;14(4):136-41. (In Ukrainian)

15. Swadzba J, Iwaniec T, Musial J. Increased level of tumor necrosis factor-a in patients with antiphospholipid syndrome: marker not only of inflammation but also of the prothrombotic state. Rheumatology International. 2011 Mar 1;31(3):307-13.

doi: $10.1007 / \mathrm{s} 00296-009-1314-8$

16. Suprun EV, Chekman IS, Belenichev IF and others. Cytokine therapy in the complex treatment of cerebrovascular diseases: state, prospects for research. Rational pharmacotherapy. 2017;1(42):1931. http://rpht.com.ua/ua-issue-article-1610. (In Ukrainian).

17. Farzaneh-Far A, Roman MJ, Lockshin MD, Devereux RB, Paget SA, Crow MK et al. Relationship of antiphospholipid antibodies to cardiovascular manifestations of systemic lupus erythematosus. Arthritis \& Rheumatism: Official Journal of the American College of Rheumatology. 2006 Dec;54(12):3918-25.

doi: 10.1002/art.22265

18. Forastiero RR, Martinuzzo ME, De Larranaga GF. Circulating levels of tissue factor and proinflammatory cytokines in patients with primary antiphospholipid syndrome or leprosy related antiphospholipid antibodies. Lupus. 2005 Feb;14(2):129-36.

doi: 10.1191/0961203305lu2048oa

19. Falcon BB. Neuroinflammation in the biochemical mechanisms of amyloidosis. Bulletin of the VN Kharkiv National University Karazin. Biology series. 2008;30:103-12. (In Ukrainian).

doi:10.26565/2075-5457-2018-30-12.

20. Yılmaz BD, Genç H, Baysal B, Eren B. The Protective Effect of Amino-guanidine, an Inducible Nitric Oxide Synthase Inhibitor, on Aluminium Sulphate Neuro-toxicity in the Rat (Wistar albino) Cerebellar Purkinje Cells: Stereological Study. Middle Black Sea Journal of Health Science. 2017;3(3):7-14. doi: $10.19127 / \mathrm{mbsjohs} .322015$

21. Salim T, Sershen CL, May EE. Investigating the role of TNF- $a$ and IFN-y activation on the dynamics of iNOS gene expression in LPS stimulated macrophages. PloS one. 2016 Jun 8;11(6):e0153289. doi:10.1371/journal.pone.0153289

22. hang GL, Wang YH, Teng HL, Lin ZB. Effects of aminoguanidine on nitric oxide production induced by inflammatory cytokines and endotoxin in cultured rat hepatocytes. World journal of gastroenterology. 2001 Jun 15;7(3):331-4.

doi: 10.3748/wjg.v7.i3.331

23. Ferreira EI, Serafim RA. Nitric Oxide Synthase Inhibitors. Nitric Oxide Synthase: Simple EnzymeComplex Roles. 2017 May 17:217.

doi:10.5772/67027.

24. Lopez-Pedrera C, Aguirre MA, Ruiz-Limon P, Perez-Sanchez C, Jimenez-Gomez Y, Barbarroja N, Cuadrado MJ. Immunotherapy in antiphospholipid syndrome. International immunopharmacology. 2015 Aug 1;27(2):200-8.

doi: 10.1016/j.intimp.2015.06.006

25. Sheybak VM, Pavlyukovets AJ. Arginine and the immune system are possible mechanisms of 
interaction. Bulletin of the Vitebsk State Medical University. 2013;12(1):6-13. (In Russian)

http://elib.vsmu.by/handle/123/6187

26. Stepanov YM, Kononov IN, Zhurbina AI et al. Arginine in medical practice (review). Journal of the Academy of Medical Sciences of Ukraine. 2004;10(1): 340-52. (In Russian)
27. Howes A, Taubert C, Blankley S, Spink N, Wu X, Graham CM, Zhao J, Saraiva M, Ricciardi-Castagnoli P, Bancroft GJ, O'Garra A. Differential production of type I IFN determines the reciprocal levels of IL-10 and proinflammatory cytokines produced by C57BL/6 and BALB/C macrophages. The Journal of Immunology. 2016 Oct 1;197(7):2838-53.

doi: 10.4049/jimmunol.1501923

Received 04 September 2019; revised 14 October 2019; accepted 25 October 2019.

This is open access article distributed under the Creative Commons Attribution License, which permits unrestricted use, distribution, and reproduction in any medium, provided the original work is properly cited. 